\title{
Anxiety and Risk Factors in Diabetes Mellitus Sufferers at Wanaraja Health Center in Garut
}

\author{
Citra Windani Mambang Sari*, Tineu Hijriani, Iwan Suhendar \\ Faculty of Nursing Universitas Padjadjaran, Jl. Raya Bandung Sumedang KM. 21, Sumedang, West Java 4536, \\ Indonesia \\ *Corresponding author: citra.windani@unpad.ac.id \\ Type of the Paper (Article)
}

Received: July 18, 2020; Accepted: August 10, 2020; Published: August 13, 2020

https://doi.org/10.29253/achnr.2020.2131

\begin{abstract}
Diabetes Mellitus (DM) is a chronic disease that remains a health problem. Sudden lifestyle changes in DM sufferers can cause anxiety. There are so many risk factors that can cause anxiety in DM sufferers, both internal and external factors. The purpose of this research was to determine the description of anxiety and risk factors that causes anxiety in DM sufferers. The research conducted using a quantitative approach. The population of this research amounted to 91 respondents using total sampling techniques. The instrument used in the form of a questionnaire, which includes: knowledge, attitudes, and anxiety using the Zung Self-Rating Anxiety Scale (SAS/SRAS). Data analysis using frequency distribution and percentage. The results showed that the majority of respondents were in the moderate anxiety level with the result of 71 (78.0\%) results. The results of this research are expected to be used as a basis for providing health education about anxiety and nursing care to reduce anxiety in patients with diabetes mellitus.
\end{abstract}

Keyword: Diabetes, risk factors, anxiety

\section{Introduction}

Diabetes mellitus is a complex chronic disease that requires prolonged medical care with multifactorial strategies such as reducing the risk of increased blood sugar levels, self-management, education, or support to prevent complications (ADA, 2018).

The incidence of diabetes mellitus will continue to increase from year to year to reach 415 million people worldwide who have diabetes mellitus (WHO, 2016). Based on data from the Basic Health Research 2018, it was reported that the number of diabetes mellitus sufferers in Indonesia was estimated to reach $1.5 \%$ or around 1,017,290 people. The prevalence of diabetes mellitus sufferers in West Java is as many as $1.3 \%$ or around 186,809 people (Riskesdas, 2018). Based on the data from Garut Health Office in 2017 the number of diabetes mellitus sufferers were 3,258 people.

In managing diabetes mellitus, apart from the involvement of doctors, nurses, nutritionists, and other health workers, the role of patients themselves and their families is also very important (PERKENI, 2015). Diabetes mellitus sufferers have many changes in their lives, which starts from the regulation of diet, exercise, control of blood sugar levels, and so on that must be done during their life. Changes in lifestyle that occur suddenly, which makes diabetes mellitus sufferers show negative psychological reactions, including anger, feeling useless, anxiety, and even depression (Ludiana, 2017). 
Various factors can influence anxiety in diabetes mellitus sufferers. Factors affecting anxiety are divided into two, namely internal and external factors, internal factors including (gender, age, levels of education) and external factors including (environment, family support, and health facilities).

Diabetes mellitus sufferers have almost twice the possibility to suffer anxiety and depression. Based on the Hospital Anxiety Depression Scale, there is evidence that high levels of anxiety and depressive symptoms in diabetics range from mild anxiety to severe anxiety (Collins, Corcoran, \& Perry, 2009).

The results of the research conducted by Hidayah (2015), states that every person with diabetes mellitus generally experiences anxious feelings about everything that happens, and is associated with diabetes mellitus, for example, feeling anxious about high blood sugar levels, or feeling anxious about complications. The impact of anxiety is that it can affect the control of blood sugar, which can cause various complications and can even cause death (Wiyadi, Loriana, \& Lusti, 2013).

Researchers have conducted a preliminary study of eight respondents, by conducting interviews that six of them said that the respondent felt anxious about his illness, and two respondents complained of anxiety because there were wounds in the foot area.

Based on the description above, diabetes mellitus remains a health problem in the world. Research on diabetes mellitus has been carried out in various places, but the prevalence of diabetes mellitus is increasing every year. Diabetes mellitus is the number 2 disease of chronic diseases in Garut Regency. Diabetes mellitus is a chronic disease that remains a health problem and can cause anxiety. The purpose of this research was to determine the description of anxiety and risk factors that causes anxiety in diabetes mellitus sufferers at Wanaraja Health Center in Garut.

\section{Research Methodology}

This research was conducted using a descriptive design with a quantitative approach. This research was conducted at Wanaraja Health Center. This research was conducted from March to May 2019. Respondents of this research were diabetes mellitus sufferers who were undergoing the treatment at Wanaraja Health Center, with a total of 91 people using a total sampling technique.

In this research, the instrument used was an anxiety questionnaire using the Zung Self-Twisting Anxiety Scale (SAS/SRAS) consisting of 20 questions. The answer to the question from the anxiety questionnaire had a score of to 4, 1 means never, 2 means sometimes, 3 means experience often, 4 always experience. The results of the total sum of each score were selected and grouped into 4 categories. Knowledge questionnaire consists of 10 questions, and answers to questions from the knowledge questionnaire had a score of 0-1 if 0 means no, 1 means yes. The results of the total sum of each score were selected and grouped into 3 categories. The attitude which consists of 10 questions consisting of positive and negative questions, answers from the attitude questionnaire had a score of 1-4 on negative questions if 1 means strongly agree, 2 means agree, 3 means disagree, 4 strongly disagree and on positive questions assessment, its reversed.

The data analysis technique used in this research was descriptive statistics so that the results will be obtained in the form of frequency distribution, then after the data is categorized the data is made in the form of a percentage. This research had received ethical approval by the Ministry of Research, Technology and High Education of Universitas Padjadjaran

\section{Research Result}

Based on Table 1, demographic characteristics data showed 31 people (34.1\%) were in the productive age, 44 people (48.4\%) were pre-elderly, and 16 people (17.6\%) were elderly. Female sex 60 people (65.9\%), and male sex 31 people (34.1\%). Respondents with an elementary education level of 14 people (15.4\%), 37 people (40.7\%) had junior high school education level, 36 people had high school education level (39.6\%) and had college education level as many as four people (4.4\%). Respondents with poor knowledge as many as 27 people (29.7\%), 61 people had sufficient knowledge (67.0\%), and three people had good knowledge (3.3\%). Respondents with poor attitude were four people $(4.4 \%)$, respondents with sufficient attitude were 80 people (87.9\%), and respondents with good attitude were seven people (7.7\%). 
Table 1. Demographic Characteristic of Diabetes Mellitus Sufferers (N=91).

\begin{tabular}{lcc}
\hline \multicolumn{1}{c}{ Characteristics } & Frequency (f) & Percentage (\%) \\
\hline Age & 31 & \\
Age 15-44 year & 44 & 34.1 \\
Age 45-59 year & 16 & 17.6 \\
Age > 60 year & & \\
\hline & 31 & 34,1 \\
Gender & 60 & 65.9 \\
Male & & \\
Female & 14 & 15.4 \\
Education & 37 & 40.7 \\
Elementary School & 36 & 39.6 \\
Junior High School & 4 & 4.4 \\
Senior High School & & \\
College & 27 & 29.7 \\
Knowledge & 61 & 67.0 \\
Poor & 3 & 3.3 \\
Sufficient & & \\
Good & 4 & 4.4 \\
Attitude & 80 & 7.7 \\
Poor & 7 & \\
Sufficient & & \\
Good & &
\end{tabular}

Table 2. Anxiety Level of Diabetes Mellitus Sufferers ( $\mathrm{N}=91)$

\begin{tabular}{ccc}
\hline Variable & Frequency (f) & Percentage (\%) \\
\hline Mild Anxiety & 20 & 22.0 \\
Moderate Anxiety & 71 & 78.0 \\
\hline
\end{tabular}

Based on table 2 above, the most respondents with diabetes mellitus had moderate anxiety level of 71 people (78.0\%), and respondents with diabetes mellitus with mild anxiety level as many as 20 people $(22.0 \%)$.

Table 3 Distribution of Health Data of Diabetes Mellitus Sufferers (N=91)

\begin{tabular}{lcc}
\hline \multicolumn{1}{c}{ Variable } & Frequency(f) & Percentage (\%) \\
\hline Duration of suffering & & \\
1 year & 24 & 26.4 \\
2 year & 34 & 37.4 \\
> 2 year & 33 & 36.3 \\
Medication & & \\
$\quad$ Oral & 70 & 76.9 \\
Insulin & 21 & 23.1 \\
Complications & & 29.7 \\
Yes & 27 & 70.3 \\
No & 64 & 100.0 \\
Blood Sugar Level & & \\
$>140$ & 91 &
\end{tabular}

Based on table 3 above, depicted 34 people sufferers with a long time suffering from 2 years (37.4\%), and treatment of 70 people (76.9\%) most of the respondents taking an oral medication, and 64 people $(70,3 \%)$ respondents did not have complications and respondents with blood sugar levels that > 140 were 91 people (100.0\%). 
Table 4. Cross Tabulation of Risk Factors and Anxiety Data of Diabetes Mellitus Sufferers (N=91)

\begin{tabular}{|c|c|c|c|c|c|}
\hline \multirow{3}{*}{ Variable } & \multicolumn{4}{|c|}{ Anxiety } & \multirow{3}{*}{ Total } \\
\hline & \multicolumn{2}{|c|}{ Mild } & \multicolumn{2}{|c|}{ Moderate } & \\
\hline & $f$ & $\%$ & $f$ & $\%$ & \\
\hline \multicolumn{6}{|l|}{ Age } \\
\hline Age (15-44year) & 8 & 25.8 & 23 & 74.2 & 100 \\
\hline Age (45-59 year) & 10 & 22.7 & 34 & 77.3 & 100 \\
\hline Age $(>60$ year $)$ & 2 & 12.5 & 14 & 87.5 & 100 \\
\hline \multicolumn{6}{|l|}{ Gender } \\
\hline Male & 7 & 22.6 & 24 & 77.4 & 100 \\
\hline Female & 13 & 21.7 & 47 & 78.3 & 100 \\
\hline \multicolumn{6}{|l|}{ Education } \\
\hline Elementary School & 3 & 21.4 & 11 & 78.6 & 100 \\
\hline Junior High School & 6 & 16.2 & 31 & 83.8 & 100 \\
\hline Senior High School & 11 & 30.6 & 25 & 69.4 & 100 \\
\hline College & 0 & 0.0 & 4 & 100.0 & 100 \\
\hline \multicolumn{6}{|l|}{ Knowledge } \\
\hline Poor & 7 & 25.9 & 20 & 74.1 & 100 \\
\hline Sufficient & 12 & 19.7 & 49 & 80.3 & 100 \\
\hline Good & 1 & 33.3 & 2 & 66.7 & 100 \\
\hline \multicolumn{6}{|l|}{ Attitudes } \\
\hline Poor & 1 & 25.0 & 3 & 75.0 & 100 \\
\hline Sufficient & 15 & 18.8 & 65 & 81.2 & 100 \\
\hline Good & 4 & 57.1 & 3 & 42.9 & 100 \\
\hline \multicolumn{6}{|l|}{ Complications } \\
\hline Yes & 4 & 14.8 & 23 & 85.2 & 100 \\
\hline No & 16 & 25.0 & 48 & 75.0 & 100 \\
\hline \multicolumn{6}{|l|}{ Blood Sugar Level } \\
\hline More than 140 & 20 & 22.0 & 71 & 78.0 & 100 \\
\hline \multicolumn{6}{|l|}{ Medication } \\
\hline Oral & 15 & 21.4 & 55 & 78.6 & 100 \\
\hline Injections & 5 & 23.8 & 16 & 76.2 & 100 \\
\hline
\end{tabular}

Based on the results of Table 4 above, in the pre-elderly age 45-59 years, most of them suffered moderate anxiety (77.3\%). Most of the female respondents suffered moderate anxiety (78.3\%). At the educational level, most respondents were at the junior high school level and had moderate anxiety $(83.8 \%)$. Most of respondents with sufficient knowledge level suffered moderate anxiety (80.3\%). Most of the respondents who had enough attitude suffered moderate anxiety (81.3\%). Respondents who did not have more complications were more than respondents with complications, the respondents who did not have complications were at the level of moderate anxiety (75.0\%). Respondents with higher sugar levels suffered moderate anxiety (78.0\%). Most of the respondents who used oral medications were in the moderate anxiety levels (78.6\%).

\section{Discussion}

In the age variable, most of the respondents were in pre-elderly age 45-59 years, who experienced moderate anxiety as many as 34 respondents with a percentage of $77.3 \%$. The results of other research said that younger respondents had higher levels of anxiety compared to older respondents because older respondents had experience in overcoming various situations such as worrying about the way diabetes mellitus treatment procedures and the influence of diabetes mellitus (Palizgir et al., 2013). In line with research conducted by Ludiana (2017), shows that the age factor can also affect the coping mechanisms of anxiety in dealing with the disease, with increasing age in a person, the person's mechanism of anxiety is weak.

In the gender variable, this research showed that female respondents were more than men, and most of the female respondents were in the moderate anxiety levels as many as 47 respondents with a percentage of 78.3\%. In line with research conducted by Ludiana (2017), gender can also affect anxiety 
in people with diabetes mellitus. The female gender is more anxiety than men, where hormones influence psychiatric in women

In the education variable, more respondents were at junior high school level and most experienced .moderate anxiety as 31 respondents with a percentage of $83.8 \%$. In line with research conducted by Hidayah (2015), where the level of education also greatly influences a person's anxiety, anxiety is most likely to occur in respondents with elementary education. Research conducted by Ludiana (2017), states that education also influences one's anxiety, where someone with an adequate level of education will be easy to identify stressors that exist in themselves.

The knowledge variable illustrated respondents had a sufficient level of knowledge in this research and mostly suffered moderate anxiety as many as 49 respondents with a percentage of $80.3 \%$. The results of other research also said that knowledge is a risk factor for anxiety in people with diabetes mellitus, where respondents with poor knowledge (51.9\%) mostly experience anxiety (Setiawan et al. 2018). This result is in line with research conducted by Wahyuni, Arsin, and Abdullah (2012), the respondents who experienced severe anxiety were mostly respondents who had low knowledge as (7.8\%) compared to respondents with a high level of knowledge as (1.9\%).

In the attitude variable, respondents who had sufficient attitudes and were in the moderate anxiety levels as many as 65 respondents with a percentage of $81.2 \%$. Based on the results of research conducted by Jauhari (2016), people with diabetes mellitus have different attitudes towards themselves and their lives. The results of research that have been done previously stated that respondents with positive attitudes did not experience severe anxiety, while respondents with negative attitudes were $8.7 \%$ (Wahyuni, Arsin, \& Abdullah, 2012).

The complications variable portrayed respondents who did not have complications were mostly in moderate anxiety as many as 48 respondents with a percentage of $75.0 \%$. Based on the results of previous research, diabetes mellitus sufferers with complications mostly experienced a high level of anxiety compared to respondents who had no complications (Collins, Corcoran, \& Perry, 2009). Research conducted by Ludiana (2017) states that when interviewing eight respondents, six of them experienced moderate anxiety, respondents said that they felt anxious about the risks of complications that might be experienced by respondents.

In the blood sugar level variable, respondents in this research had more than 140 blood sugar level and were in the moderate anxiety level. The results of research conducted by Dewi (2018), stated that there was a relationship between anxiety factors with the control of blood sugar levels with the results of respondents with proper blood sugar control levels of $80 \%$ were at mild anxiety levels, and respondents with uncontrolled blood sugar levels of $23.3 \%$ were at mild anxiety level. In line with Litae and Purba (2019), stated that respondents who experienced mild anxiety levels with a result of blood sugar levels $<200 \mathrm{mg} / \mathrm{dL}$ as many as (23.1\%) and with blood sugar levels $>200 \mathrm{mg} / \mathrm{dL}$ as many as (21.5\%), while for respondents with moderate anxiety levels with blood sugar levels $<200 \mathrm{mg} / \mathrm{dL}$ (24.6\%) and with blood sugar levels $>200 \mathrm{mg} / \mathrm{dL}(30.8 \%)$.

The treatment variables represented respondents mostly used oral insulin, and respondents who used oral insulin were in the moderate anxiety levels as 55 respondents with a percentage of $78.6 \%$. The results of previous research that the administration of insulin can affect people with diabetes mellitus on anxiety level (Kartika, Rosa and Permana, 2016). In line with research conducted by Jauhari (2016), people with diabetes mellitus have anxiety level related to treatment that must be undertaken.

\section{Conclusion}

Based on the results of research conducted on 91 respondents of diabetes mellitus sufferers at Wanaraja Health Center in Garut, it was found that as many as 44 people (48.4\%) were elderly, female gender as many as 60 people (65.9\%), respondents with junior high school education level as many as 37 people (40.7\%), respondents with a sufficient level of knowledge were 61 people (67.0\%), most respondents had enough attitude with the results of 80 (87.9\%), and respondents who had no complications as many as 64 people (70.3\%), the majority of respondents with blood sugar levels $>140$ were $(100.0 \%)$, the respondents who used oral medications were 70 people (76.9\%), and most respondents were in the moderate anxiety level with a result of $71(78.0 \%)$.

Referring to the result above, it is recommended, that this research be used as an input for program managers regarding to the prevention of anxiety in diabetes mellitus sufferers by intensifying counseling 
about anxiety and the effects of anxiety. This risk factor must be anticipated to finish the process of treating diabetes mellitus. It is expected that further research will examine the risk factors that cause anxiety in people with diabetes mellitus in greater depth and regarding other risk factors that cause anxiety in diabetes mellitus sufferers.

\section{References}

American, A. D. (2018). Standards Of Medical Care In Diabetes. The Journal of Clinical And Applied Research And Education, 41(January).

Collins, M. M., Corcoran, P., \& Perry, I. J. (2009). Psychology Anxiety and depression symptoms in patients with diabetes. Journal Compilation 2009 Diabetes UK. Diabetic Medicine, 26, 153-161, 153-161. https://doi.org/10.1111/j.1464-5491.2008.02648.x

Dewi, E. U. (2018). Hubungan Tingkat Kecemasan Terhadap Terkendalinya Gula Darah Pada Pasien Diabetes Melitus Di Puskesmas Pakis Surabaya. Keperawatan, 6(1).

Hidayah, N. (2015). Study Tingkat Kecemasan Penderita Diabetes Mellitus Di Poli Rawat Jalan Puskesmas Ngawi Purba Kabupaten Ngawi, 32-37.

Jauhari. (2016). Dukungan Sosial Dan Kecemasan Pada Pasien Diabetes Melitus. The Indonesian Journal of Health Science, Vol 7, No. 1, Desember 2016, 7(1), 64-76.

Kartika, Rosa, Permana, P. (2016). Pengaruh Shalat Dalam Menurunkan Tingkat Ansietas Dan Kadar Glukosa Darah Pada Pasien Diabetes Mellitus Tipe 2. Journal Ilmiah Keperawatan Dan Kesehatan, (1), 45-5

Ludiana. (2017). Hubungan Kecemasan Dengan Kadar Glukosa Darah PenderitaDiabetes Mellitus Di Wilayah Kerja Puskesmas Sumbersari Bantul Kec. Metro Selatan Kota Metro. Wacana Kesehatan Vol.1, No.1,Juli 2017, 1(1)

Litae, L., Purba, M. M., \& Febriani, I. F. (2019). Hubungan Tingkat Kecemasan Dengan Peningkatan Kadar Gula Darah Klien Diabetes Mellitus. Husada Mahakam, 4(8), 474-482.

Perkeni (2015). Pengelolaan dan Pencegahan Diabetes Mellitus Tipe 2 di Indonesia. PB. PERKENI.

Palizgir, M., Bakhtiari, M., \& Esteghamati, A. (2013). Association of Depression and Anxiety With Diabetes Mellitus Type 2 Con- cerning Some Sociological Factors, 15(8), 644-648. https://doi.org/10.5812/ircmj.12107

Ragil Wahyuni, A. Arsunan Arsin, A. Z. A. (2012). Faktor Yang Berhubungan Dengan Tingkat Kecemasan Pada Penderita Diabetes Mellitus Tipe II Di Rs Bhayangkara Andi Mappa Oudang Makasar. Bagian Epidemiologi Fakultas Kesehatan Masyarakat Universitas Hasanuddin, 1-3.

Riskesdas. (2018). National Riskesdas Report. Kementerian Kesehatan RI Badan Penelitian Dan Pengembangan Kesehatan.

Setiawan, H., Sopatilah, E., Rahmat, G., Wijaya, D. D., \& Ariyanto, H. (2018). Hubungan Tingkat Pengetahuan dengan Kecemasan Penderita Diabetes Mellitus. University Research Colloqium 2018, 241-248.

Wahyuni, RA. Arsunan Arsin, A. Z. A. (2012). Faktor Yang Berhubungan Dengan Tingkat Kecemasan Pada Penderita Diabetes Mellitus Tipe II Di Rs Bhayangkara Andi Mappa Oudang Makasar. Bagian Epidemiologi Fakultas Kesehatan Masyarakat Universitas Hasanuddin, 1-3.

Wiyadi, Rina Loriana, J. L. (2013). Hubungan Tingkat Kecemasan Dengan Kadar Gula Darah Pada Penderita Diabetes Mellitus. JurnalHusada Mahakam, 3(6), 263-271.

World Health Organization. (2016). Global Report On Diabetes. 
